\title{
Toxocariasis as a cause of multiple pulmonary nodules in a paediatric patient
}

\author{
Andrew Gemmell
}

Department of Radiology, Plymouth Hospitals NHS Trust, Devon, UK

Correspondence to Dr Andrew Gemmell, agemmell14@hotmail.com

Accepted 15 December 2014

\section{DESCRIPTION}

An asymptomatic 8-year-old boy with a history of myasthenia gravis presented for MRI thorax to assess for a thymoma. The child had a chronic history of pica that involved the consumption of stones and mud.

Incidental MRI findings included multiple, circumscribed soft tissue nodules present in both lungs (figure 1) and a small area of abnormal signal intensity in the right liver lobe.

Subsequent contrast-enhanced CT revealed multiple ill-defined nodules throughout both lungs (figure 2). All nodules demonstrated an ill-defined halo. No cavitation, hilar or mediastinal lymphadenopathy was identified. The liver demonstrated multiple, poorly-enhancing lesions. Routine haematology and biochemistry revealed iron-deficiency anaemia and eosinophilia $(4.04 \times 109 / \mathrm{L})$.

The imaging findings, eosinophilia and subsequent positive serological testing for Toxocara, interpreted in conjunction with the history of pica, were considered strongly suspicious for toxocariasis. Following treatment with Albendazole, resolution of the hepatic lesions was confirmed by MRI after 4 weeks and the majority of lung nodules had resolved following 3 months.

Pulmonary nodules in a paediatric patient should raise the possibility of toxocariasis especially if suitable risk factors are identified such as pica or the

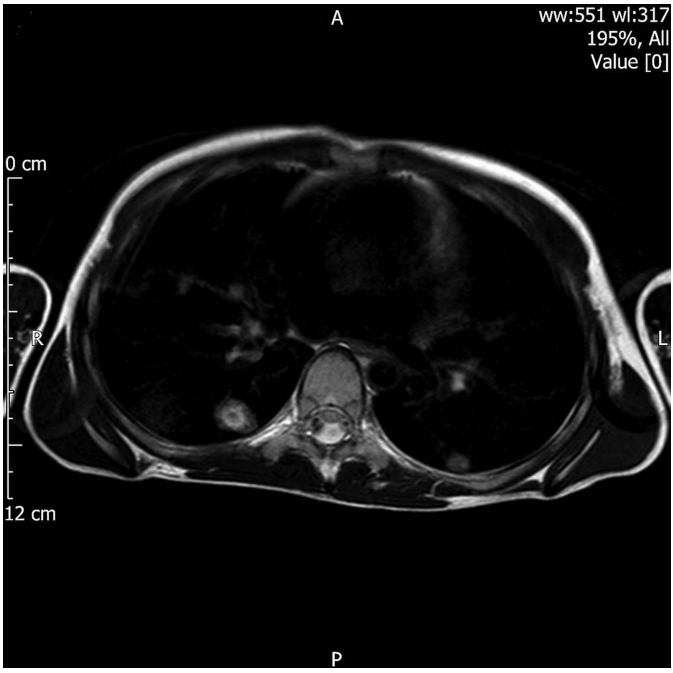

Figure 1 Axial T2-weighted MRI of the thorax. There is a $1.6 \mathrm{~cm}$ rounded nodule in the posterior aspect of the right lower lung lobe and a smaller, less well-defined $0.8 \mathrm{~cm}$ nodule in the posterior left lower lobe. Additional nodules were present throughout both lungs.

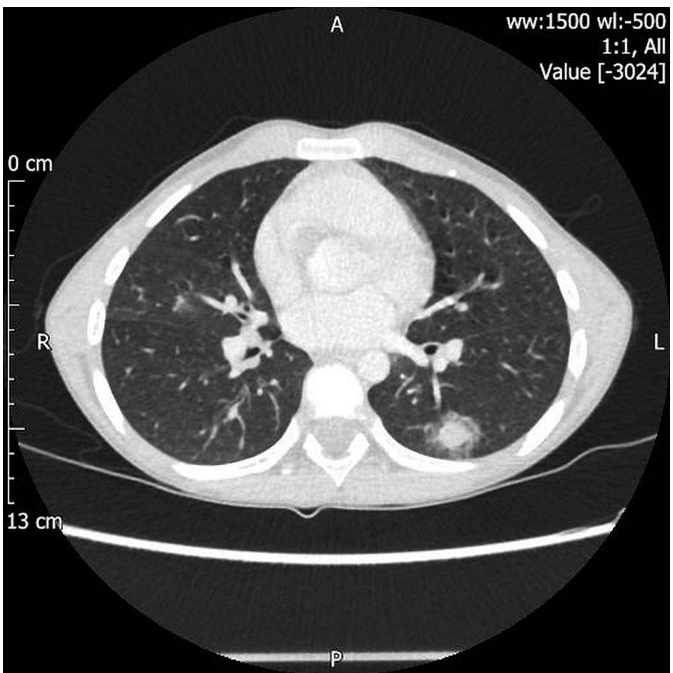

Figure 2 Contrast-enhanced axial CT image of the chest. There is a well-defined nodule in the lower lobe of the left lung demonstrating an ill-defined halo.

consumption of raw meat. CT findings include multiple pulmonary nodules with or without a halo of ground glass opacity and focal ground glass opacity. ${ }^{1} 2$ In patients subjected to follow-up imaging, nodules may demonstrate lesion migration due to the host response to wandering larvae. ${ }^{2}$ Multiple, poorly enhancing hepatic lesions are also typical reflecting the characteristics related to granuloma and abscess formation. ${ }^{3}$

\section{Learning points}

- Humans are accidental hosts of Toxocara spp zoonotic nematodes of the dog, cat and fox.

- Infection is usually asymptomatic, however, larval migration through host tissues induces eosinophilic inflammation and may lead to a range of imaging findings depending on the organ or tissue affected.

- The imaging findings in pulmonary visceral larva migrans are non-specific and include multiple pulmonary nodules with or without a halo of ground glass opacity and focal ground glass opacity on contrast-enhanced CT.

- The incidental finding of multiple pulmonary nodules in a paediatric patient should raise the possibility of toxocariasis, especially if eosinophilia and suitable risk factors are identified such as pica or the consumption of raw meat.
Case Rep Published online: 207073 
Competing interests None.

\section{Patient consent Obtained.}

Provenance and peer review Not commissioned; externally peer reviewed.

\section{REFERENCES}

1 Hur JH, Lee IJ, Kim JH, et al. Chest CT findings of toxocariasis: correlation with laboratory results. Clin Radiol 2014;69:e285-90.

Copyright 2015 BMJ Publishing Group. All rights reserved. For permission to reuse any of this content visit http://group.bmj.com/group/rights-licensing/permissions.

BMJ Case Report Fellows may re-use this article for personal use and teaching without any further permission.

Become a Fellow of BMJ Case Reports today and you can:

- Submit as many cases as you like

- Enjoy fast sympathetic peer review and rapid publication of accepted articles

- Access all the published articles

- Re-use any of the published material for personal use and teaching without further permission

For information on Institutional Fellowships contact consortiasales@bmjgroup.com

Visit casereports.bmj.com for more articles like this and to become a Fellow
2 Sakai S, Shida Y, Takahashi N, et al. Pulmonary lesions associated with visceral larva migrans due to Ascaris suum or Toxocara canis: imaging of six cases. AJR Am J Roentgenol 2006;186:1697-702.

3 Ortega CD, Ogawa NY, Rocha SM, et al. Helminthic diseases in the abdomen: an epidemiologic and radiologic overview. Radiographics 2010;30:253-67. 